\title{
The Role of Audit Committee in Corporate Governance
}

\author{
Aishwarya.R, B. Sangeetha Tomer
}

\begin{abstract}
Corporate governance has played a vital role in the business world, especially after the increased overall money related emergencies. Systematic corporate governance is viewed as an important aspect to acknowledge and include an association in a large portion of the stock trade showcases all around the globe. The audit committee undertakes a significant role in company or corporate governance in relation with the association's course, authority, and duty. The audit committee is responsible for managing the association's exposure and procedure, promising that the federation or association follows the significant neighborhood and international laws, justifiable measures and standards conforming to the association's internal decree. The objective of the study is to examine the association between the nature of the audit committee and the gender and find the association between the requirement of audit committee in a company and age. For the purpose of this study, descriptive research is used Convenient sampling method is used to collect the 1493 samples.Independent variables are age, gender. The dependent variables are the nature of the audit committee and the requirement of the audit committee in a company. The study concludes that the nature of the audit committee is associated with age and the requirements of the audit committee in a company is associated with age.
\end{abstract}

Keywords: Audit Committee, corporate governance,ethics, role, powers, responsibilities.

\section{INTRODUCTION}

The roles and responsibilities of the audit committee is dealt under section 177 of the recent Companies Act, 2013. The necessity of an audit committee in a company or a body corporate was initially introduced in earlier Companies Act,1956. Audit committee is a body constituted with highly disciplined and efficient individuals in the field of accounting and finance. The object of this committee is to strengthen and govern the management in public companies and also lead the board of directors in discharging their functions effectively. The Companies Act, 2013 recognizes the significance of a review board of trustees and depends it with extra jobs and obligations. The duty of the audit committee is to manage the association's subjection, procedures, conditions such as significant neighbourhood and international laws, morale measures and standards which are followed by the association or the company. The audit committee deals with association's administration, legal counsellors, and other general direction and consistent dangers. Corporates may also have a main consistence

Revised Manuscript Received on November 19, 2019

Aishwarya.R, BBA,LLB(HONS) 1st year, Saveetha school of law,saveetha university,SIMATS,Chennai, Tamilnadu, India. (Email: aishu.25aish@gmail.com)

B. Sangeetha Tomer, Associate professor, Saveetha school of law,saveetha university,SIMATS,Chennai, Tamilnadu, India. . (Email: sangeethab.ssl@saveetha.com)
Committee or moral officials with whom the review board of trustees or the audit committee can talk about the risks and dangers found with the set of accepted rules. The recent trends in the audit committee was explained in an African news article which says at present the audit committee is exhibits a vital role in company or corporate governance in relation with the organisation's direction, control and accountability and also it is agreed that the audit committee will be playing a wider corporate governance role in the future, and also the major parties in the governance field will support the committee or the board strongly. By doing the above mentioned rules, the audit committee will be able to perform the hierarchical powers over the management, which will assign the power to the accountant and the outcome would reap in the form of authentic financial reports of the company.

\section{OBJECTIVES}

1. To understand the role of audit committee in the corporate governance.

2. To study the powers of the audit committee in a company

3. To study the association between the nature of the audit committee and gender

4. To examine the association between the requirements of an audit committee in a company and age.

\section{REVIEW OF LITERATURE}

(Ghiasi et al. 2019) has discussed that at present, the audit committee plays a significant role in corporate governance in accordance with the association's bearing, power and duty. Usually the audit committee has performed a more important part in corporate or company administration. Bradley (2019) has analysed ranking directors and free inspectors likewise have particular jobs in the budgetary announcing process. (Böhm; Ewer et al. 2019) has studied that directors are liable for setting up the fiscal summaries and building up inner powers over budgetary announcing and discussed that managers should likewise keep up the inner controls and guarantee that the monetary revealing procedure is exact and viable. (Singareddy et al. 2018) has studied that independent auditors bears the duty regarding communicating a supposition on the reasonableness of the fiscal summaries, the organization's money related position, operational results and incomes and guaranteeing that those issues accommodate with proper accounting rules.(Böhm, Bollen, and Hassink 2016)has put forth that before the audit committee starts its work, panel individuals should see how the board creates and reports inward monetary data. Braiotta et al.

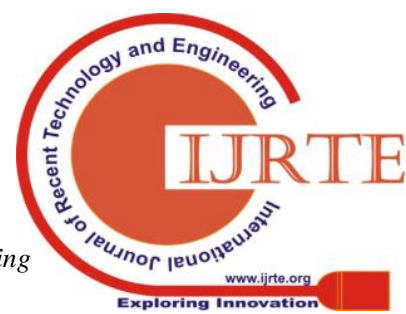




\section{The Role of Audit Committee in Corporate Governance}

(2013) has studied that checking on inside data offers audit councils a chance to pose inquiries about the culmination, precision and practicality of audit documents. A decent comprehension of audit reports guarantees the review board of trustees to realize the potential effect of budget reports. All audit committee individuals should likewise be up to speed on ongoing proficient and administrative changes and declarations. (Moran and Kral 2010) has examined auditing is an interactive procedure between the audit committee, examiners and the higher authorities. The audit panels survey the aftereffects of the audit alongside the directors and outer evaluators, with the board of auditors under general examining models. Australian Institute of Company Directors (2008) has analysed that the essential duties of the board of auditors is to analyse noteworthy accounts pronounce the issues if any. Audit panels are particularly unique in relation to different boards of trustees in that they have more authority than most different sorts of councils. Spira( 2007) has examined the extraordinary association with outside examiners and the significance of their obligations, it's essential for audit committee to have authority over their financial limits and for overseeing outer auditors.Nolan and McFarlan (2005) has studied organizations that have an inner review office, the review advisory group surveys and favors the review plan, audits staffing and gives knowledge over the association of the review plan. The review board of trustees additionally meets with inward evaluators and the board to get in contact for occasional survey. (Verschoor and Institute of Internal Auditors 2000)has studies during the review the audit committee may propose elective review approaches and organize the review with inner review staff. It's significant for review boards of trustees to move in the direction of anticipating extortion.(Ruangswadipong 1997)auditors with forensic audit ability are adroit at distinguishing tenacious bookkeeping mistakes and anomalies. The review process is intended to secure speculators, and the expectation is that investors will have trust in the monetary reports that the organization discharges.

\section{METHODOLOGY}

For the purpose of this study is descriptive research is used to portray accurately the role of audit committee in corporate governance. Random or convenient sampling method is used to collect the samples. The sample size is 1493. This study was carried out to portray accurately the role of audit committee in corporate governance. The independent variables are gender and age. The dependent variables are the nature of audit or accounts committee and the requirements of audit committee.

\section{DATA ANALYSIS \& RESULTS}

\section{HYPOTHESIS:}

H0: There is no significant association between the nature of the audit committee and gender of

the respondent Ha: There is a significant association between the nature of the audit committee and gender of the respondent

TABLE 1: Chi-square test - The nature of the audit committee in corporate and Gender

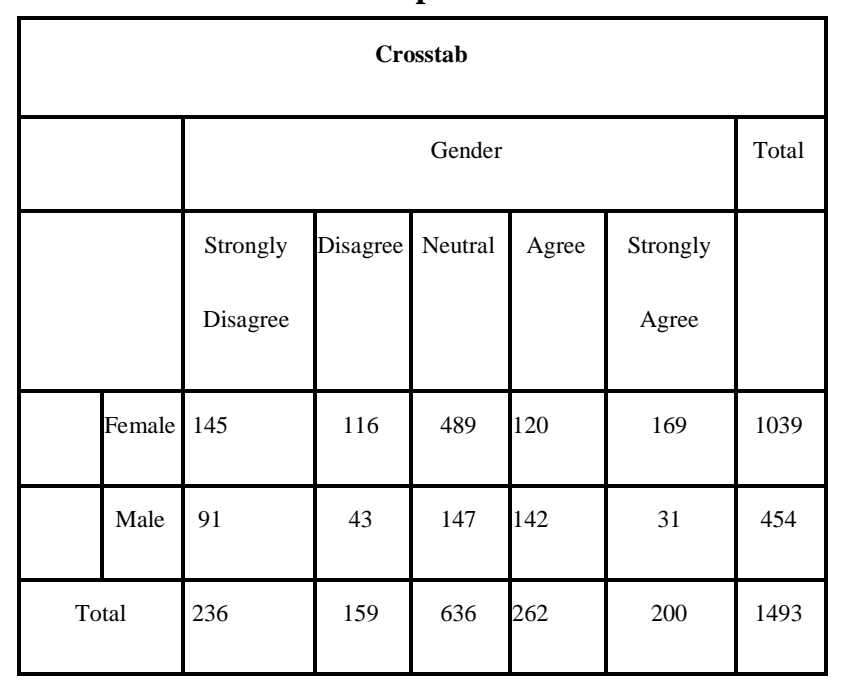

SOURCE: Primary

data

TABLE2:

\begin{tabular}{|c|c|c|c|}
\hline \multicolumn{4}{|c|}{ Chi-Square Tests } \\
\hline & Value & $\mathrm{df}$ & $\begin{array}{l}\text { Asymp. Sig } \\
\text { (2-sided } \\
\text { ) }\end{array}$ \\
\hline Pearson Chi-Square & 115.332 & 4 & .000 \\
\hline $\begin{array}{c}\text { Likelihood } \\
\text { Ratio }\end{array}$ & $\begin{array}{c}112.37 \\
6\end{array}$ & 4 & .000 \\
\hline $\begin{array}{l}\text { Linear-by-Linea } \\
\text { r } \\
\text { Association }\end{array}$ & 2.020 & 1 & .155 \\
\hline $\begin{array}{c}\mathrm{N} \text { of Valid } \\
\text { Cases }\end{array}$ & 1493 & & \\
\hline
\end{tabular}

SOURCE: Primary data

\section{INTERPRETATION :}

From the above table it has been found that the p-value is less than 0.05 so reject the null hypothesis. The alternative hypothesis has been accepted therefore there is a significant association between the nature of the audit committee and gender of the respondent. So the nature of the audit committee is associated with age.

\section{HYPOTHESIS:}

H0: There is no significant association between the requirement of audit committee in a company and age

Ha: There is a significant association between the requirement of audit committee in a company and age 
TABLE-3:Chi-square test- The requirement of Audit committee in a company and Age

\begin{tabular}{|l|l|l|l|l|l|}
\hline \multicolumn{5}{|c|}{ Crosstab } \\
\hline \multicolumn{2}{|c|}{} & \multicolumn{3}{|c|}{ AGE } & Total \\
\hline & & yes & no & Maybe & \\
\hline age & $18-30$ & 271 & 500 & 123 & 894 \\
\hline & $30-40$ & 367 & 182 & 45 & 594 \\
\hline Total & 638 & 682 & 168 & 1493 \\
\hline
\end{tabular}

SOURCE: Primary data

TABLE- 4:

\begin{tabular}{|c|c|c|c|}
\hline \multicolumn{4}{|c|}{$\begin{array}{c}\text { Chi-Square } \\
\text { Tests }\end{array}$} \\
\hline & Value & df & $\begin{array}{l}\text { Asymp. Sig. } \\
\text { (2-sided) }\end{array}$ \\
\hline $\begin{array}{l}\text { Pearson } \\
\text { Chi-Square }\end{array}$ & $\begin{array}{r}\mathrm{a} \\
144.317\end{array}$ & 2 & .000 \\
\hline Likelihood Ratio & 145.421 & 2 & .000 \\
\hline $\begin{array}{l}\text { Linear-by-Linear } \\
\text { Association }\end{array}$ & 114.427 & 1 & .000 \\
\hline $\mathrm{N}$ of Valid Cases & 1488 & & \\
\hline
\end{tabular}

SOURCE: Primary data

INTERPRETATION: From the above table it has been found that the p-value is less than 0.05 so reject the null hypothesis. The alternative hypothesis has been accepted. Therefore, there is a significant association between the nature of the audit committee and gender of the respondent. Hence it can be concluded that the requirement of audit committee is associated with age.

\section{CONCLUSION}

The role of the audit committee is to shape the foundation for strong corporate administration. The Boards of directors and the other authorities depended on the audit committee to offer viable oversight of the yearly inspection procedure. Members of the audit committee performed the most prominent work in maintaining and updating the financial records of the company. The process of auditing is an interactive one between the directors, committee, auditors and the managers of the company. The committee will review the results of the audit for the financial year including the matters that the managers generally share and discuss with the audit committee. The significant and primary duty of the audit committee is to review the financial and managerial issues. So from this study it is analysed that the nature of the audit committee and the gender of the respondent are associated with each other and the requirements of the audit committee and the age of the respondent are associated with each other. This study suggests that the top level managers of the companies holding an audit committee must compose it very efficiently with dedicated individuals who are expertised in the field of finance and accounting so as to carry out the work relating to the accounts and financial departments very effectively.

\section{REFERENCE}

1 Adelopo, Ismail. 2016. Auditor Independence: Auditing, Corporate Governance and Market Confidence.Routledge.

2 Australian Institute of Company Directors. 2008. Audit Committees: A Guide to Good Practice.AICD.

3 Böhm, Falko, Laury H. Bollen, and Harold F. Hassink. 2016. "Audit Committee Charter Scope: Determinants and Effects on Audit Committee Effort." International Journal of Auditing.https://doi.org/ 10.1111/ijau.12060.

4 Bradley, Fintan L. 2019. "Radiotherapy Dosimetry Audits Carried out in Ireland at the Request of the National Radiation Safety Committee in 2014 \& 2017." Physica Medica: PM: An International Journal Devoted to the Applications of Physics to Medicine and Biology: Official Journal of the Italian Association of Biomedical Physics(September): 94-98.

5 Braiotta, Louis, Jr., R. Trent Gazzaway, Robert Colson, and Sridhar Ramamoorti. 2010. The Audit Committee Handbook.John Wiley \& Sons.

6 Collier, Paul, and Zaman Mahbub. 2005. "Convergence in European Corporate Governance: The Audit Committee Concept." Corporate Governance: An International Review.https://doi.org/ 10.1111/j.1467-8683.2005.00468.x.

7 Ewer, Andrew K., Sanjeev A. Deshpande, Christopher Gale, Benjamin J. Stenson, Michele Upton, Claire Evans, and Sam J. Oddie. 2019. "Potential Benefits and Harms of Universal Newborn Pulse Oximetry Screening: Response to the UK National Screening Committee Public Consultation." Archives of Disease in Childhood, July. https://doi.org/ 10.1136/archdischild-2019-317859.

8 Ghiasi, Ashraf, Afsaneh Keramat, Maryam Farjamfar, and Katayon Vakilian. 2019. "Perceived Barriers to Accessing Pregnancy-Related Health Information among Married Adolescent Women: A Qualitative Study in Iran." Journal of Pediatric and Adolescent Gynecology ,August. https://doi.org/10.1016/j.jpag.2019.08.012.

9 Lipman, Frederick D., and L. Keith Lipman. 2006. Corporate Governance Best Practices: Strategies for Public, Private, and Not-for-Profit Organizations.John Wiley \& Sons.

10 Moran, Sheila, and Ronald Kral. 2013. The Board of Directors and Audit Committee Guide to Fiduciary Responsibilities: Ten Crtical Steps to Protecting Yourself and Your Organization.AMACOM.

11 Nolan, Richard, and F. Warren McFarlan. 2005. "Information Technology and the Board of Directors." Harvard Business Review83 (10): 96-106, 157.

12 Rafie Manesh, Hosein, Kamran Yazdani, Saharnaz Nedjat, Alireza Noroozi, John B. Saunders, Ramin Mojtabai, and Afarin Rahimi-Movaghar. 2019. "Alcohol Use Disorders Identification Test (AUDIT): Validation of the Persian Version in an Iranian Population." Alcohol ,August. https://doi.org/10.1016/j.alcohol.2019.08.002.

13 Riishede, M., C. B. Laursen, L. S. Teglbjærg, E. Rancinger, P. B Pedersen, S. M. Luef, J. H. Clausen, O. Graumann, A. T. Lassen, and G. Baatrup. 2019. "Diagnostic Value of Whole-Body-Focused Ultrasonography in High-Acuity Patients in the Emergency Department: A Prospective Single-Center Cross-Sectional Study." The Ultrasound Journal11 (1): 11

14 Ruangswadipong, Jaruwan. 1997. Corporate Governance Improvement with Audit Committee.

15 Ruppel, Warren. 2006. Not-for-Profit Audit Committee Best Practices. John Wiley \& Sons.

16 Singareddy, Raja R. R., Shabana Chandrasekaran, Balamurugan Annamalai, and Pratyush Ranjan. 2018. "Corporate Governance Data of 6 Asian Economies (2010-2017)." Data in Brief20 (October): $53-56$. 
The Role of Audit Committee in Corporate Governance

17 Spira, Laura F. 2007. The Audit Committee: Performing Corporate Governance.Springer Science \& Business Media.

18 Verschoor, Curtis C., and the Institute of Internal Auditors. 2000. Audit Committee Briefing: Understanding the 21st Century Audit Committee and Its Governance Roles. 